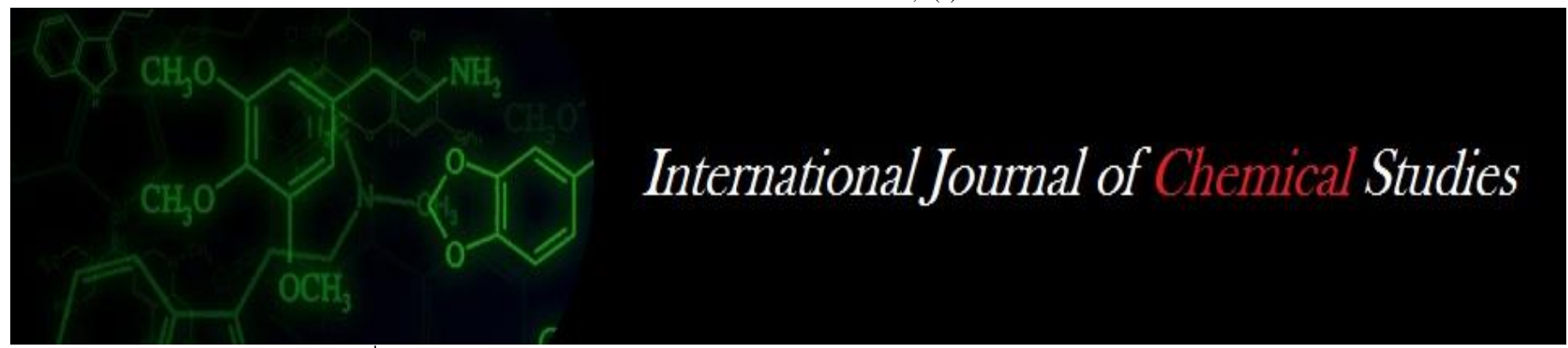

P-ISSN: 2349-8528

E-ISSN: 2321-4902

www.chemijournal.com

IJCS 2020; 8(6): 1769-1771

(C) 2020 IJCS

Received: 13-09-2020

Accepted: 26-11-2020

Dhananjay K Atole

M.Sc. Agriculture,

Department of Plant Pathology,

Mahatma Phule Krishi

Vidyapeeth, Rahuri,

Maharashtra, India

Dr. KS Raghuwanshi

Associate Professor,

Department of Plant Pathology,

College of Agriculture Dhule,

Dhule, Maharashtra, India

Monali N Pawar

M.Sc. Agriculture,

Department of Plant Pathology,

Mahatma Phule Krishi

Vidyapeeth, Rahuri,

Maharashtra, India

Sanganna S Kumbhar

M.Sc. Agriculture,

Department of Plant Pathology,

Mahatma Phule Krishi

Vidyapeeth, Rahuri,

Maharashtra, India

\section{Morphological and cultural studies of Alternaria alternata causing leaf spot and fruit rot of chilli}

\author{
Dhananjay K Atole, Dr. KS Raghuwanshi, Monali N Pawar and \\ Sanganna S Kumbhar
}

DOI: https://doi.org/10.22271/chemi.2020.v8.i6y.11024

\begin{abstract}
Leaf spot and fruit rot of chilli caused by Alternaria alternata (Fr.) Keissler is one of the most destructive disease of chilli (Capsicum anпиum L.). Study was undertaken to conduct collection of samples, isolation, identification, pathogenicity, morphological and cultural characters of pathogen on different culture media in vitro. The isolations were made from the symptomatic samples collected from chilli plot from All India Coordinated Research Project on Vegetable Crops, Mahatma Phule Krishi Vidyapeeth, Rahuri. The isolation of fungal pathogen was done from affected samples of chilli leaf. Further purified and maintained on PDA media. Pathogenicity of test fungal pathogen was proved on healthy chilli plant in earthen pots under glasshouse conditions. The pathogen was identified as Alternaria alternata on the basis of morphological and cultural characteristics. The pathogen showed typical symptoms of leaf spot on chili in glasshouse. Alternaria alternata showed spots with concentric rings on leaves. Alternaria causes small reddish purple spots most characteristic symptom was brown to dark spots on older leaves. The circular spots enlarge and soon develop dark, concentric rings or ridges gaved target-like appearance. Lesion growth stopped by major leaf veins. Spotted leaves soon turn yellow, wither and died. In cultural studies, it was observed that the fungal test pathogen Alternaria alternata showed maximum radial growth and excellent sporulation on PDA media.
\end{abstract}

Keywords: Alternaria alternata (fr.) keissler, culture media, in vitro, leaf spot and fruit rot, concentric rings, sporulation, fungal colony, muriform

\section{Introduction}

India, being the largest chilli producer, has vast potentiality to increase production and promote export besides meeting its domestic requirements. However, despite continuous efforts at various levels, the chilli productivity did not gain accepted momentum. This could be attributed to various biotic and abiotic constraints. Among the biotic stress fungus causing most common widely distributed diseases. Chilli attacked by a large number of fungal diseases depending upon the locality and agro climatic conditions.

Leaf spot and fruit rot disease caused by Alternaria alternata (Fr.) Keissler is becoming a limiting factor and posing a major problem in chilli production. The pathogen has been reported to cause seed, seedling, leaf and fruit diseases as well as Post harvest decay of fruit and seed has also been reported due to this pathogen. Alternaria leaf spot fungus, survives in or on seed as tiny black stromata in old affected leaves in the soil. Infection occurs by direct penetration to the leaf. Alternaria spores required high humidity in the atmosphere for germination and penetration to the host; however, heavy dew is sufficient for infection of the pathogen. The disease is most severe during periods of warm temperatures and excessive moisture either from rain or overhead irrigation. The fungus is spread by splashing water, wind, and leaf-to-leaf contact.

\section{Material and Methods}

Collection of diseased sample and isolation of pathogen

The disease sample was collected from the infected chilli plot

Research Project on Vegetable Crops, Mahatma Phule Krishi Vidyapeeth, Rahuri, Ahmednagar, Maharashtra, India. Samples showing typical symptoms were used for isolation of pathogens under study and the culture obtained was used for further investigation.
Dhananjay K Atole

Department of Plant Pathology,

Mahatma Phule Krishi

Vidyapeeth, Rahuri,

Maharashtra, India 
The common laboratory medium i.e., Potato dextrose agar (PDA) media was used for isolating the fungal pathogen responsible for leaf spot and fruit rot of chilli. The organism repeatedly sub-cultured on potato dextrose slants for maintaining the pure culture for further studies.

\section{Morphological Characters}

Morphological characters such as mycelia width, length and width of conidia, colony colour, and type of margin, colour of margin, mycelial growth and sporulation were measured under compound microscope. The length, breadth, colour and number of septations and the shapes of spore were also recorded.

\section{Cultural Characters}

The variation in cultural characters of Alternaria alternata was studied on the different solid media and the best media for the fungus growth was identified. The growth characters of the fungus were studied on eight different solid media. All the media were sterilized at $121{ }^{\circ} \mathrm{C}$, at 15 pounds pressure for 15 minutes. Twenty $\mathrm{ml}$ of each of the medium was poured in to $90 \mathrm{~mm}$ diameter petridishes. Such plates were inoculated with five $\mathrm{mm}$ disc of fungal growth and incubated at $27 \pm$ $1{ }^{\circ} \mathrm{C}$. Each treatment was replicated thrice. Colony diameter was recorded by averaging the linear growth of the colony in two directions for each plate after 5, 7, and 9 day of inoculation. The fungal colony colour, surface elevation and sporulation were also recorded at the end of the incubation period. The data on radial growth was analysed statistically. The different media used in the studies viz., PDA media, Oat meal agar, Corn meal agar, Richard's medium, Martin's medium, V-8 juice agar, Host leaf dextrose agar, and Carrot extract agar medium.

\section{Result and Discussion \\ Morphological Characters \\ 1. Mycelium}

The fungus produced profuse mycelial growth on PDA. Initially, the mycelium was hyaline that turned to greybrownish, multi celled, septate and irregularly branched. In early growing stage, hyphae were thin, narrow and hyaline but became slightly thick as they grew old.

\section{Conidia}

Conidia were born in chains up to 10 or more on conidiophores. They were light olivaceous to dark brown in colour, varied in shape from obclavate to mostly ellipsoidal, muriform having tapered apex with 1 to 3 longitudinal and 210 transverse septa. The muriform conidia inclusive of beak measured $47.16 \mu \mathrm{m}(21.82-96.40 \mathrm{~mm}) \times 8.26-16.52 \mu \mathrm{m}$ (13.49 mm). The length of the condium was 3-5 times (2.64 to 5.84 times) more than its width. The beak measured $27.12 \mu \mathrm{m}$ (22.62 - $58.69 \mu \mathrm{m})$ in length.

\section{Conidiophores}

Conidiophores arised singly or in clusters, usually 2-6 and were long or short. They were pale olivaceous to olivaceous brown, straight or curved, geniculate, slightly swollen at apex having terminal scars indicating the point of attachment of conidia. The conidiophores measured $41.12 \mu \mathrm{m}$ (26.20-114 $\mu \mathrm{m})$ in length and $4.31 \mu \mathrm{m}(3.25-8.21 \mu \mathrm{m})$ in width. The length: width ratio was 9.85 (8.75 -13.29).

\section{Chlamydospores}

The chlamydospores were formed in the old culture of $A$. alternata. They were intercalary, thick walled, roundish to oval in shape, dark brown in colour and measuring $7.22 \mu \mathrm{m}$ (4.92 - $9.89 \mu \mathrm{m})$ in diameter.

Similar result was obtained by Nagrale et al., (2013) ${ }^{[6]}$ who recorded morphological observations of A. alternata by adopting slide culture technique. Devappa and Thejakumar (2016) ${ }^{[2]}$ studied that the culture of the fungal colony was initially white, cottony with profuse aerial mycelium which gradually turned grey colour. Aged culture appeared completely greyish with aerial mycelium and distinct concentric rings was formed on medium. Conidiophores were short to long, simple or branched arising singly. Conidiophores were golden to brown coloured with 2-9 transverse and 0-2 longitudinal septa. Conidia were born in long chains (6-11) on conidiophores, they were thick walled, beaked and brown in colour.

\section{Cultural characters}

The variation in cultural characters of Alternaria alternata was studied on the eight different solid media. And the results thus obtained are presented in Table 1,2 and Fig. 2. The radial growth, colony characters and sporulation of the fungi were recorded, when the maximum growth was attained on any one of the tested media. The effect of different culture media on the growth of fungi differed significantly. Maximum radial growth of $A$. alternata was recorded on PDA media $(88 \mathrm{~mm})$, which was found to be significantly superior to all other media followed by Richard's medium $(85 \mathrm{~mm})$, V-8 juice agar $(77.50 \mathrm{~mm})$, Martin's and Carrot extract agar $(75 \mathrm{~mm})$, Corn meal agar $(70 \mathrm{~mm})$ and Oat meal agar $(65$ $\mathrm{mm})$. The least radial growth was recorded in Host leaf dextrose agar media $(37.50 \mathrm{~mm})$. Mycelium colour varied from grayish to brownish. The growth varied from flat to raised and fluffy to sparse. Pigmentation in the media also varied from brown, pinkish, white and black. Sporulation also showed greater variation in different media, ranging from excellent to poor. Excellent sporulation was recorded on PDA Media, good sporulation in Oat meal agar, Carrot extract agar, and Richard's medium, moderate sporulation in Corn meal agar and Host leaf dextrose agar, poor sporulation was recorded in Martin's medium while sporulation was not recorded in V-8 media.

Table 1: Growth of Alternaria alternata on different solid media

\begin{tabular}{|c|c|c|c|c|}
\hline \multirow{2}{*}{ Sr. No. } & \multirow{2}{*}{ Media } & \multicolumn{3}{|c|}{ Mean colony diameter (mm)* } \\
\cline { 3 - 5 } & & 5 DAI & 7 DAI & 9 DAI \\
\hline 1. & PDA Media & 50 & 65 & 88 \\
\hline 2. & Oat meal agar & 53 & 60 & 65 \\
\hline 3. & V-8 juice agar & 41 & 61 & 77.50 \\
\hline 4. & Carrot extract agar & 50 & 60 & 75 \\
\hline 5. & Corn meal agar & 55 & 65 & 70 \\
\hline 6. & Richard's medium & 60 & 75 & 85 \\
\hline 7. & Martin's medium & 61 & 67 & 75 \\
\hline 8. & Host leaf dextrose agar & 20 & 25 & 37.50 \\
\hline & S.E. \pm & 0.86 & 0.90 & 0.95 \\
\hline & CD at 5\% & 2.58 & 2.70 & 2.87 \\
\hline & CD at 1\% & 3.55 & 3.75 & 3.95 \\
\hline
\end{tabular}

* Each value is the mean of three replications, Note: DAI: Days after inoculation 
Table 2: Cultural characteristics and sporulation of Alternaria alternata on different solid media after 9 days of incubation

\begin{tabular}{|c|c|c|c|}
\hline Sr. No. & Media & Growth characteristics & Sporulation \\
\hline 1. & PDA Media & Brownish, fluffy over growth with regular margins and concentric rings. & ++++ \\
\hline 2. & Oat meal agar & Blackish growth with irregular margins, good mycelia growth & +++ \\
\hline 3. & V-8 juice agar & Brownish in colour, irregular growth. & - \\
\hline 4. & Carrot extract agar & Dark brownish in colour, uniform, concentric rings with uniform margin. & +++ \\
\hline 5. & Corn meal agar & Dark brown to black, uniform and regular margins. & ++ \\
\hline 6. & Richard's medium & Greyish, fluffy growth black with margin. & +++ \\
\hline 7. & Martin's medium & Dull greyish, fluffy growth with regular and circular margin. & + \\
\hline 8. & Host leaf dextrose agar & Greyish, fluffy over growth with irregular margin, with slow mycelia growth. & ++ \\
\hline
\end{tabular}

Here, $-=$ No sporulation, $+=$ Poor sporulation,$++=$ Moderate sporulation, $+++=$ Good sporulation, $++++=$ Excellent sporulation

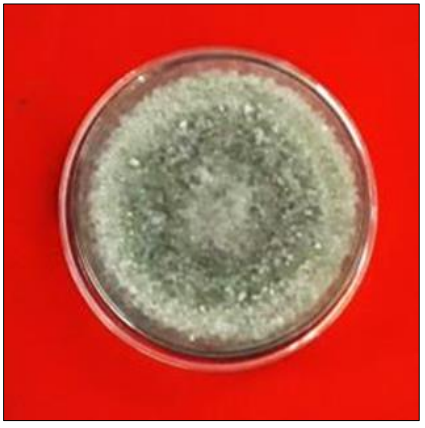

(A) Pure culture

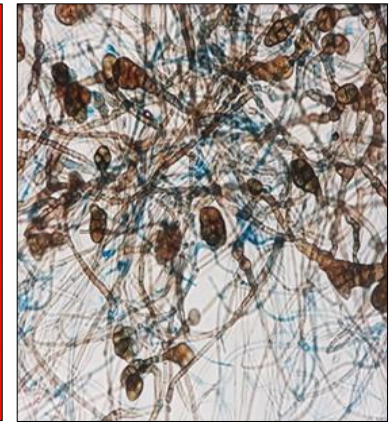

(B) Mycelium and spores

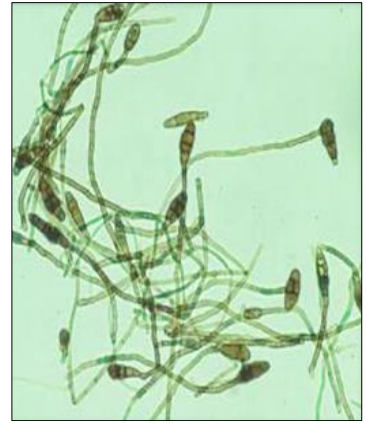

(C) Conidiophore

Fig 1: Pure culture (A) and microphotograph (B, C) of Alternaria alternata

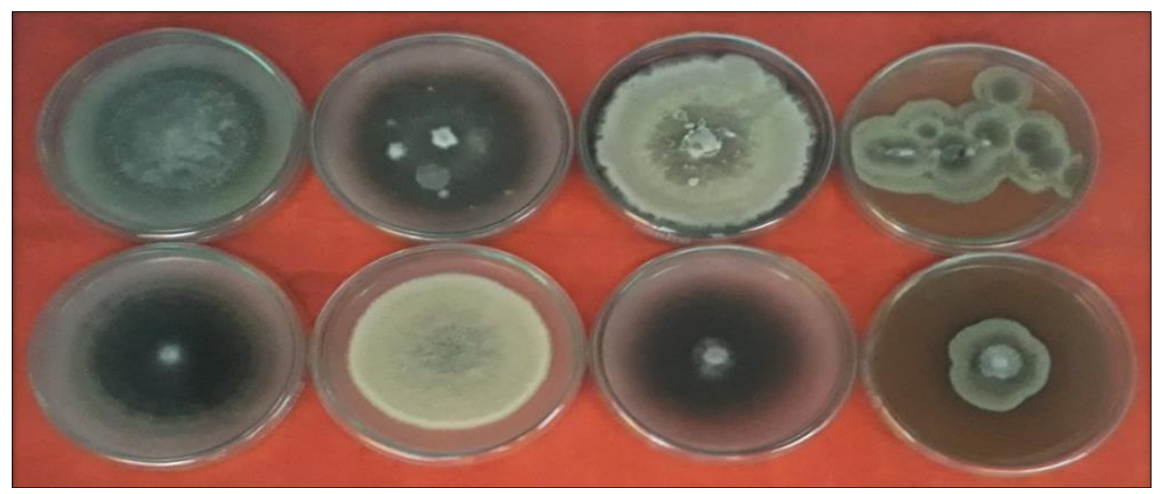

1. PDA media, 2. Corn meal agar, 3. Richard's medium, 4. V-8 juice agar, 5. Carrot extract agar, 6. Martin's medium, 7. Oat meal agar, 8. Host leaf dextrose agar

Fig 2: Growth of Alternaria alternata on different solid media

\section{References}

1. Bhatt JC, Gahlain A, Pant SK. Record of Alternaria alternata on tomato, capsicum and spinach in Kumaon Hills. Indian Phytopath 2000;53(4):495-496.

2. Devappa V, Thejakumar MB. Morphological and physiological studies of Alternaria alternata causing leaf spot disease of Chilli (Capsicum annuum L.), International Journal of Applied and Pure Science and Agriculture (IJAPSA) 2016;2(5)26-30.

3. Ginoya CM, Gohel NM. Cultural and morphological variability among the Isolates of Alternaria alternata (Fr.) Keissler incident of fruit rot of chilli. International Journal of Plant Protection 2015;8(1):118-125.

4. Klimesova M, Prasil K. Morphological variability of the conidia of Alternaria alternata (Hypomycetes). Novitates Botanicae Universities, Carolinae 1989;5:7-27.

5. Maheshwari SK, Singh DV, Sahu AK. Effect of several media on the growth and sporulation of Alternaria alternata. J Mycopathol Res 2001;37:21-23.

6. Nagrale DT, Gaikwad AP, Sharma L. Morphological and cultural characterization of Alternaria alternata (Fr.) Keissler blight of gerbera. Journal of Applied and Natural Science 2013;5(1):171-178.
7. Pandey BN, Srivastva SP, Srivastva RK. Studies on effect of various culture media on growth, sporulation and morphological variations of Alternaria alternata (Fr.) Keissler. Flora and Fauna Jhansi 2006;12(2):247248.

8. Shekhawat N, Trivedi A, Sharma SK, Kumar A. Cultural, morphological and pathogenic variability in Alternaria burnsii causing blight of cumin. J Mycol Pl Path 2013;43 (1):80-83.

9. Singh RP, Singh AK. Cultural variability in wheat isolates of Alternaria triticina. Farm Science Journal 2003;12:168-169. 